\title{
A Mobile 3D Serious Game that Operates like a Pure-Tone Air Conduction Hearing Test
}

\author{
Paul Hatzigiannakoglou ${ }^{1}$, Areti Okalidou ${ }^{1}$, VC. Georgopoulos ${ }^{2}$ \\ University Of Macedonia \\ Egnatia 156, Thessaloniki, Greece \\ pxatzi@uom.gr \\ ${ }^{2}$ TEI of Western Greece \\ Megalou Alexandrou1, Patra, Greece \\ voula@teiwest.gr
}

\section{Extended Abstract}

In this paper, we present a Mobile 3D serious game that operates like a Pure-Tone Air Conduction Hearing Test and uses the principles of Conditioned Play Audiometry (CPA) [1]. The end users are preschool children and this fact leads us to choose the touch screen, as an input device, considering that this response mode should be more appropriate for such ages [2]. The application is designed to be used outside a sound booth. At the design phase, we adopted techniques that audiologists use during the hearing test with children that are older than 2,5 years old, to overcome difficulties like boredom, denial to participate, and cases where the child is unable to wear headphones (CPA) [2]. The aim of the application is to offer the audiologists or speech-language pathologists a preparatory tool for training children in responding to a pure tone audiometry test. The training helps them to overcome difficulties related to attention or response mode and converts the medical test into a cheerful 3D game for children [3]. The user's performance during the test is recorded, giving the ability to assess readiness for the actual audiometric evaluation that takes place in the clinic. The application also allows the order of the produced tones to be chosen by the audiologist or speech-language pathologist, providing the possibility of adjusting the test to any individual.

\section{References}

[1] J. R. Madell, C. Flexer, "Pediatric audiology: Diagnosis, technology, and management," Thieme, 2013.

[2] K. Yimtae, P. Israsena, P. Thanawirattananit, S. Seesutas, S. Saibua, P. Kasemsiri, A. Noymai, and T. Soonrach, "A Tablet-Based Mobile Hearing Screening System for Preschoolers: Design and Validation Study," JMIR mHealth and uHealth, vol. 6, no. 10, 2018.

[3] "Chapter II: Pure Tone Tests of Children Above the Age of Three Years," Acta Oto-Laryngologica, vol. 46, no. sup128, pp. 7-29, 1956. 